\title{
Informacja z Wyższej Szkoły Ekonomicznej w Sopocie na temat sytuacji po wydarzeniach marcowych
}

Piotr Abryszeński | Wydział Historyczny, Uniwersytet Gdański

Słowa kluczowe:

Wyższa Szkoła

Ekonomiczna

w Sopocie,

Marzec 1968,

represje

Keywords:

Higher School

of Economics

in Sopot,

March 1968 protests,

repressions

Wydarzenia marcowe cieszą się dużym zainteresowaniem badaczy. W ostatnich latach ukazało się wiele publikacji omawiających zarówno centralne, jak i lokalne aspekty kryzysu politycznego 1968 roku'. Obchodzona niedawno 50. rocznica studenckich protestów przyniesie niewątpliwie nowe ustalenia, zaś głos ówczesnych studentów przyczyni się być może do zainspirowania dalszych badań nad problematyką wydarzeń marcowych (Abryszeński, Gucewicz 2018; Konieczka, 2018)

W marcu 1968 r. w Wyższej Szkole Ekonomicznej w Sopocie studiowało przeszło 4 tys. studentów, z czego niemal $60 \%$ na studiach wieczorowych, zaocznych lub eksternistycznych. Jeżeli weźmiemy się pod uwagę położenie uczelni, nie może dziwić, że jej studenci byli raczej słabo zintegrowani ze społecznością akademicką. Dla porównania na największej trójmiejskiej uczelni - Politechnice Gdańskiej studiowało wówczas ponad 8,3 tys. osób, z czego ponad 6 tys. na studiach dziennych. Należy również przyznać, że w czasie tych wydarzeń WSE odgrywała rolę drugoplanową, zaś centrum gdańskiego Marca 1968 roku stanowiła Politechnika.

Przywołany poniżej dokument (Informacja z Wyższej Szkoły Ekonomicznej w Sopocie) pochodzi z Archiwum Państwowego w Gdańsku (Informacja, 1968: 52-54) i jest podsumowaniem represji wymierzonych przeciwko najaktywniejszym uczestnikom studenckiego protestu wywodzącym się z WSE, należy go jednak traktować jedynie jako wycinek pewnej rzeczywistości.

Informacja... powstała zapewne na przełomie marca i kwietnia 1968 r., a więc w czasie osłabienia studenckich protestów

1 W kontekście podjętej w niniejszym artykule tematyki zob. przede wszystkim: Andrzejewski 2008, Cenckiewicz 2008. Szeroką panoramę wydarzeń 1968 roku nakreślił Eisler 2006. 
w Trójmieście. Była odpowiedzią na zapytanie Komitetu Wojewódzkiego na temat bieżącej sytuacji panującej w WSE. Nie dysponujemy wprawdzie owym dokumentem, jednakże na podstawie treści cytowanej informacji możemy ustalić kwestie, jakimi interesowali się decydenci. Pierwsza dotyczyła związków studentów z zakładami pracy na terenie Trójmiasta. Ta - z punktu widzenia partii newralgiczna sprawa - w dużo większym stopniu odnosiła się jednak do studentów innych uczelni, zwłaszcza Politechniki Gdańskiej. Odbywali oni wówczas praktyki w strategicznych zakładach, jak Stocznia Gdańska, w których w okresie strajków studenckich dochodziło do rozpropagowywania ulotek i afiszy o treściach antypaństwowych i nawołujących do wystąpień. Sporządzający Informację... podaje, że w tym czasie tylko jedna osoba odbywała praktyki, wyróżniając jedynie praktyki letnie oraz obowiązkowe praktyki dyplomowe. Dopiero ustawa o szkolnictwie wyższym z 1968 r. ureguluje kwestie praktyk, czyniąc z nich narzędzie dyscyplinujące młodzież akademicką.

Decydenci z Komitetu Wojewódzkiego obawiali się ponownych wystąpień i obserwowali nastroje panujące w środowisku akademickim, dlatego też zobowiązali władze trójmiejskich uczelni do pilnowania porządku na swoim terenie oraz informowania nie tylko o ewentualnych wystąpieniach, ale i ryzyku wystąpień. Nie były to obawy nieuzasadnione, bowiem ostatnim z wyraźnych marcowych akcentów był wiec zorganizowany 5 kwietnia na Politechnice Gdańskiej w obronie aresztowanych Andrzeja Biernasia i Ryszarda Konieczki - jednakże studenci WSE w tym wydarzeniu nie uczestniczyli.

Warto w tym kontekście przyjrzeć się problematyce represji, jakie zastosowano wobec uczestników zajść marcowych. Do 15 marca zatrzymano 54 studentów (w tym 36 z Politechniki Gdańskiej). Postępowanie karne wszczęto wobec 19 osób, z czego 12 stanowili studenci Politechniki. Może zastanawiać fakt, że na tej liście nie znalazł się żaden student Akademii Medycznej czy Wyższej Szkoły Pedagogicznej, natomiast aż pięć osób studiowało na WSE. Przeciwko aktywnym uczestnikom protestów wkrótce wszczęto postępowania dyscyplinarne, a wymienieni zostali decyzją rektora zawieszeni w prawach studenta ${ }^{2}$. Skala represji zastosowanych wobec studentów wymaga jednak oddzielnego opracowania.

W jednym z dokumentów z 16 kwietnia podana jest informacja, że decyzją rektora Stanisława Ładyki ${ }^{3}$ ukarano 70 studentów WSE, z czego aż 43 osoby miały zostać skreślone z listy studentów ${ }^{4}$. Należy przy tym wspomnieć, że w wyniku pomarcowych represji z pracy usunięto asystentkę Katedry Ekonomiki Transportu, Annę Kunert (Andrzejewski 2008: 164-165).

\footnotetext{
2 Wykaz studentów, 1968: 58-62. Szerzej na temat represji zob. także Andrzejewski (2008: 108-119).

3 Stanisław Ładyka (1928-2012) - profesor nauk ekonomicznych, w latach 1964-65 dziekan Wydziału Morskiego WSE, a w latach 1965-1969 rektor WSE. Doktor honoris causa Uniwersytetu Gdańskiego (2011).

4 Zapewne zdecydowana większość z nich, jeżeli nie wszyscy, została rychło przywrócona w poczet studentów. Sprawa ta wymaga jednak dalszych badań, por. Górecki (1968: 202), Cenckiewicz (2008: 263).
} 
Specyficzną formą wpływania na postawy studentów było odwoływanie się do ich rodziców. To właśnie oni mieli dopilnować dzieci. W przypadku Politechniki Gdańskiej przyjęło ono szczególnie kuriozalną formę: otóż decyzją prorektora PG Stanisława Rydlewskiego wysyłano listy do rodziców uczestników wspomnianego wiecu z 5 kwietnia (Andrzejewski 2008: 287-294). Powszechne było stosowanie rozmów dyscyplinujących i wychowawczych, w których uczestniczyli przedstawiciele uczelni, czasem i przedstawiciele prokuratury oraz władz. Przez informowanie rodziców o „niewłaściwej postawie” ich dzieci wywierano szczególny rodzaj presji zarówno na studentów, jak i na najbliższych. Groźba relegowania z studenta uczelni nie mogła ich pozostawić obojętnymi.

Warto zwrócić uwagę na ostatnie zdanie zawarte w informacji, które dotyczy ustnych ustaleń między władzami uczelni a partią. Otóż po ustaleniach przedstawicieli władz WSE z sekretarzem KW Tadeuszem Wrębiakiem uczelnia wystąpiła o umorzenie toczących się spraw wobec studentów. Praktyka ta, zapewne powszechna na wszystkich trójmiejskich uczelniach, przyniosła zróżnicowane skutki. Nie wszyscy studenci doczekali się pozytywnego załatwienia ich spraw.

Postępowanie karne wszczęto w stosunku do pięciu studentów WSE. Marek Kałamajski, Wiesław Kopiec i Jan Lindner zostali zatrzymani pod zarzutem rzucania kamieniami w funkcjonariuszy MO 15 marca 1968 r. (Stasiak, 1968: 24; Miklas, 1968b: 126), natomiast Tadeusz Jabłoński - pod zarzutem brania "udziału w nielegalnym zbiegowisku, którego celem było zmuszenie funkcjonariuszy MO do zaniechania wykonania czynności służbowych" (Wykaz studentów, 1968: 61). Autor Informacji... podaje, że w przypadku Tadeusza Jabłońskiego prokurator "zrezygnował z wymogu stanu zawieszenia w prawach studenta", choć w jednym z wcześniejszych dokumentów zawarta jest informacja, że 20 marca został on zawieszony przez rektora. Wobec trzech studentów uchylono areszt tymczasowy i zamieniono na dozór MO: Wiesława Kopca, Jana Lindnera i Adama Safinowskiego. Decyzję tę podjęto jeszcze przed 21 marca na wniosek rektora WSE (por. także Miklas, 1968a: 121-125).

Sprawy karne dotyczące studentów WSE wkrótce umorzono. Do sierpnia 1968 r. toczyły się sprawy studentów Politechniki - Ryszarda Mosakowskiego i Wojciecha Woźniaka, natomiast w 1969 r. uniewinniono Józefa Kurzydłę.

Dane dotyczące uczestników wydarzeń marcowych są nieścisłe i obarczone licznymi błędami, badacz często bowiem napotyka na pomyłki w nazwiskach oraz afiliacji zatrzymanych, również w oficjalnych (prokuratorskich!) dokumentach. Dowodem tego jest choćby osoba Mariana Jerzego Kujawy5. Udział środowiska akademickiego sopockiej Wyższej Szkoły Ekonomicznej w studenckich protestach z marca 1968 dopiero czeka na naukowe opracowanie. Do pogłębienia wiedzy na ten temat przyczyniłaby się niewątpliwie kwerenda w zbiorach Instytutu Pamięci Narodowej oraz Archiwum Państwowym w Gdańsku. Ze względu na stan zachowania źródeł "marcowych"

5 Prawdopodobnie był on studentem WSP. 
oraz upływający czas należałoby również podjąć próbę dotarcia do uczestników strajków z 1968 r.

$$
* * *
$$

W cytowanym tekście nieznacznie poprawiono pisownię. Zrezygnowano również z oznaczenia podkreśleń odręcznych w maszynopisie.

\section{Informacja z Wyższej Szkoły Ekonomicznej w Sopocie}

1. W obecnym okresie na praktyce znajduje się tylko jedna studentka Wyższej Szkoły Ekonomicznej - studentka V r. Zofia Kozarzewska-Wenta - praktyka w Wojewódzkiej Pracowni Planów Regionalnych w Gdańsku; praktyka zostanie zakończona dnia 20 kwietnia br.

Jest to praktyka odbywana w późniejszym terminie, przesunięta z uwagi na urlop macierzyński, z którego korzystała wyżej wymieniona.

W normalnym trybie praktyki w naszej Uczelni odbywają się:

- praktyki wakacyjne - w sierpniu i wrześniu,

- praktyki dyplomowe - od września do grudnia.

2. Na terenie Uczelni nie nastąpiły jak dotychczas żadne tego rodzaju szczególne przypadki, które wymagałyby dyscyplinarnego ustosunkowania się władz Uczelni w stosunku do studentów.

3. Natomiast $w$ związku z zajściami w dniu 15 marca br. we Wrzeszczu pismem prokuratora wojewódzkiego z dnia 18 marca br. otrzymaliśmy informację dotyczącą niewłaściwego zachowania się kilku studentów WSE. Z treści tego pisma wynikało, iż:

w stosunku do pięciu studentów, a mianowicie:

Adama Safinowskiego

Wiesława Kopca

Jana Lindnera

Tadeusza Jabłońskiego

Marka Kałamajskiego

Prokurator wszczął postępowanie karne (a w stosunku do 3 najpierw wymienionych zastosował areszt tymczasowy, który następnie został zamieniony na dozór milicyjny). W związku z tym zostali oni czasowo zawieszeni w prawach studenta.

W stosunku do wymienionego Tadeusza Jabłońskiego w dniu 22 marca br. prokurator zrezygnował z wymogu stanu zawieszenia w prawach studenta. 
Ponadto w piśmie prokuratora wymieniono 3 dalsze nazwiska:

Andrzeja Wawryka

Mariana Jerzego Kujawy

Eugeniusza Jażdżewskiego,

w stosunku do których prosił o zastosowanie odpowiednich kroków ze strony Uczelni. Należy zauważyć, iż wymieniony Marian Jerzy Kujawa podany został przypadkowo, ponieważ nie figuruje w spisach naszych studentów.

Sprawa udziału studentów WSE w incydentach z dnia 15 marca br. potraktowana została przez władze Uczelni i społeczność akademicką jako zagadnienie szczególnej wagi.

Ze względu na nadzwyczajny charakter tych wydarzeń postanowiono - niezależnie od zawieszenia w prawach studenta - wyżej wymienionych czterech studentów - sięgnąć do szerszego arsenału środków społecznego i wychowawczego oddziaływania, jakimi może dysponować Uczelnia. W związku z tym do ustosunkowania się do samej sprawy, jak też wywarcia swego moralnego wpływu włączone zostały obok Senatu Uczelni także zespoły kierownicze organizacji młodzieżowych. Włączeni zostali także rodzice wymienionych studentów w tych przypadkach gdzie istnieje stan postępowania karnego. W dniu 23 oraz 25 marca br. rektor Uczelni ${ }^{6}$ w obecności dziekana Wydziału Morskiego ${ }^{7}$ odbył indywidualne rozmowy z zawezwanymi specjalnie w tym celu rodzicami.

W dniu 27 marca br. rektor Uczelni w obecności zespołu Senatu Uczelni, a także w obecności prokuratora ob. K. Kruczalaka odbył kolejne spotkanie z zawezwanymi w tym celu studentami - Markiem Kałamajskim, Wiesławem Kopcem, Januszem Lindnerem i Tadeuszem Jabłońskim ${ }^{8}$. W następnych dniach podobne rozmowy odbyły się ze studentami nie mającymi wytoczonego postępowania karnego: Andrzejem Wawrykiem i Eugeniuszem Jażdżewskim. W czasie tych spotkań wyżej wymienionym studentom udzielono należnego im ostrego upomnienia oraz ostrzeżenia co do dalszego ich zachowania się w ramach społeczności akademickiej.

W przypadku pierwszych pięciu wymienionych studentów mających postępowanie karne Uczelnia wystąpiła zgodnie z ustaleniami z Sekretarzem Komitetu Wojewódzkiego tow. T[adeuszem] Wrębiakiem o umorzenie sprawy.

\section{Literatura}

Abryszeński P., Gucewicz D. (red.), 2018, Marzec 1968 na Politechnice Gdańskiej w dokumentach, Gdańsk: Instytut Pamięci Narodowej.

Andrzejewski M., 2008, Marzec 1968 w Trójmieście, Warszawa-Gdańsk: Instytut Pamięci Narodowej.

6 Funkcję tę pełnił wówczas Stanisław Ładyka.

7 Funkcję tę pełnił wówczas Tadeusz Łodykowski (1928-2006).

8 Nazwisko Tadeusza Jabłońskiego nadpisano odręcznie. 
Cenckiewicz S., 2008, Trójmiejski marzec'68. Próba obalenia Gomułki przez SB? (w:) S. Cenckiewicz, Oczami bezpieki. Szkice i materiały z dziejów aparatu bezpieczeństwa PRL, Kraków: Wydawnictwo Arcana.

Eisler J., 2006, Polski rok 1968, Warszawa: Instytut Pamięci Narodowej.

Informacja z Wyższej Szkoły Ekonomicznej w Sopocie, 1968, [brak autora], syg. Komitet Wojewódzki Polskiej Zjednoczonej Partii Robotniczej w Gdańsku, nr 2492, Gdańsk: Archiwum Państwowe w Gdańsku.

Konieczka K. (red), 2018, Marzec 1968 na Politechnice Gdańskiej w oczach uczestników, Gdańsk: Instytut Pamięci Narodowej (w przygotowaniu do druku).

Rocznik statystyczny województwa gdańskiego 1969, 1969, Gdańsk: Wojewódzki Urząd Statystyczny.

Górecki K., 1968, Meldunek dzienny, syg.: AIPN Gd, 0046/41, t. 3, Gdańsk: Oddziałowe Archiwum Instytutu Pamięci Narodowej w Gdańsku.

Miklas J., 1968a, Informacja w sprawie polityki represyjnej stosowanej przez organa ścigania wobec studentów, którzy w toku zajść w dniach 12 i 15 marca 1968 r. weszli w kolizję z prawem karnym, Gdańsk, 21 III 1968, syg.: AIPN Gd, 05/41, t. 1, Gdańsk: Oddziałowe Archiwum Instytutu Pamięci Narodowej w Gdańsku.

Miklas J., 1968b, Propozycje represji wobec uczestników studenckich, syg.: AIPN Gd, 05/41, t. 1, Gdańsk: Oddziałowe Archiwum Instytutu Pamięci Narodowej w Gdańsku.

Stasiak H., 1968, Meldunek specjalny nr 3, Gdańsk, 16 III 1968, syg.: Komitet Wojewódzki Polskiej Zjednoczonej Partii Robotniczej w Gdańsku, nr 1832, Gdańsk: Archiwum Państwowe w Gdańsku.

Wykaz studentów wyższych uczelni Wybrzeża, przeciwko którym wszczęto postępowanie karne z powodu udziału w zajściach 12 i 15 III 1968 r., 1968, [brak autora] syg.: Komitet Wojewódzki Polskiej Zjednoczonej Partii Robotniczej w Gdańsku, nr 2492, Gdańsk: Archiwum Państwowe w Gdańsku. 